\title{
Autoimmune Polyglandular Syndrome Type 2 (APS-2) in A 70-Year-Old Woman: A Case Report
}

\author{
Shahin Besharati 1(D), Pouria Tavakkolian ${ }^{2 *}$ (D), Roghayeh Borji 1 (iD
}

1. Metabolic Diseases Research Center, Zanjan University of Medical Sciences, Zanjan, Iran

2. Student Research Center, Zanjan University of Medical Sciences, Zanjan, Iran

\begin{tabular}{|c|c|}
\hline Article Info & ABSTRACT \\
\hline doi $10.30699 / j a m b s .27 .124 .47$ & \multirow{3}{*}{$\begin{array}{l}\text { Type } 2 \text { autoimmune polyglandular (Schmidt) syndrome (APS-2) is defined by the } \\
\text { occurrence of at least } 2 \text { out of } 3 \text { of the following manifestations, Addison's disease, } \\
\text { Hypothyroidism and Type } 1 \text { diabetes mellitus. APS- } 2 \text { is a rare condition with an } \\
\text { incidence of } 1-2 / 100000 \text { per year. Prevalence of APS- } 2 \text { is most happening in the } \\
\text { range of } 20-40 \text { years of age. Here we present a patient who complained about loss of } \\
\text { appetite with significant weight loss also having trouble with her skin saying she had } \\
\text { experienced progressively darkening of the skin all over her body and manifestations } \\
\text { of Addison's disease at the age of } 70 \text {. The patient was treated with oral Prednisolone, } \\
\text { Fludrocortisone and Levothyroxine and evaluated after one month which showed the } \\
\text { hormonal panel within the normal range. }\end{array}$} \\
\hline $\begin{array}{c}\text { Received: 2019/03/04; } \\
\text { Accepted: 2019/04/10; } \\
\text { Published Online: 10 Jul 2019; }\end{array}$ & \\
\hline $\begin{array}{c}\text { Use your device to scan and read the } \\
\text { article online }\end{array}$ & \\
\hline
\end{tabular}

Keywords: Autoimmune polyglandular syndrome, Addison's disease, Hypothyroidism, Schmidt Syndrome

Corresponding Information:

Pouria Tavakkolian, Student Research Center, Zanjan University of Medical Sciences, Zanjan, Iran E-Mail: elgar.tavakkolian@gmail.com

\begin{tabular}{|c|c|}
\hline (c) (1) (8) & $\begin{array}{l}\text { Copyright } \odot 2019 \text {, This is an original open-access article distributed under the terms of the Creative Commons Attribution-noncommercial } 4.0 \text { International License which permits } \\
\text { copy and redistribution of the material just in noncommercial usages with proper citation. }\end{array}$ \\
\hline
\end{tabular}

\section{Introduction}

Autoimmune polyglandular syndromes (APSs) consist of clinical conditions caused by loss of immune tolerance leading to functional defect of multiple endocrine glands and are identified with circulating autoantibodies and lymphocytic infiltration of the affected tissues or organs. This process will consequently end in organ failure (1). There are three main syndromes impairing endocrine system, APS-1, APS-2 and APS-3. Moreover another category occurs in patients having cancer whom are treated with immunoregulatory agents, in which tumor antigens that have steered clear of recognition could be attacked at the expense of activating autoimmunity (2). APS-2 is diagnosed when at least 2 out of 3 manifestations are present in an individual including primary adrenal insufficiency (Addison's disease), autoimmune thyroid disease-causing Grave disease or hypothyroidism and type 1 diabetes mellitus (T1DM). Other endocrine and non-endocrine manifestations of APS-2 are as following: celiac disease, alopecia, vitiligo, primary hypogonadism, myasthenia gravis, IgA deficiency, pernicious anemia, idiopathic heart block, Stiff-man syndrome, Parkinson's disease, serositis, dermatitis herpetiformis, idiopathic thrombocytopenia, and hypophysitis (3). It is worth mentioning that this syndrome was first well understood by Schmidt in 1926, who reported the co-existence of hypothy- roidism and adrenal insufficiency in patients with lymphocytic infiltration of both the thyroid and adrenal glands and so on; the terms APS-2 and Schmidt Syndrome are used interchangeably (4). In keeping with other autoimmune diseases, APS-2 is also more prevalent in women with the female-to-male ratio of 3$4: 1$. Prevalence of APS-2 is most happening in the range of 20-40 years of age $(1,2,5)$.

\section{Case Report}

A 70-year-old East-Mediterranean woman presented with generalized fatigue that had been going on for two months and had been developing gradually. In addition she had trouble doing the daily chores. The patient had no medical history previously and did not take any drugs either. Patient also complained about loss of appetite and she had lost around $10 \mathrm{~kg}$ over the last year. Moreover she had been having trouble with her skin saying she had experienced progressively darkening of the skin all over her body and on her hands and her face to be precise, over the last 10 years. Patient had no history of smoking or usage of either opium or alcohol. 
On physical examination, the patient was lethargic and had low blood pressure: $90 / 60 \mathrm{mmHg}$ with orthostatic hypotension. Hyperpigmentation of the skin (Figures 1 and 2) and mucus membranes were seen (Figures 3 and 4). Thyroid was found smaller than the normal size while palpating. With the impression of thyroid and adrenal issues following laboratory investigations were made.

According to high levels of serum thyroid stimulating hormone (TSH) and low levels of T4, the patient was diagnosed with hypothyroidism (Table 1). Furthermore, low level of $\mathrm{Na}$ and high level of $\mathrm{K}$ in company with high level of ACTH and low level of Cortisol along with the skin and mucosal manifestations, led us to diagnosis of Primary Adrenal Insufficiency (Table 2).
Adrenal failure was managed with $7.5 \mathrm{mg}$ oral Prednisolone daily and $0.1 \mathrm{mg}$ oral Fludrocortisone daily. She was also treated with levothyroxine $0.1 \mathrm{mg}$ daily as a Hormone replacement therapy due to hypothyroidism.

Further evaluations were made one month later in order to follow $\mathrm{Na}$ and $\mathrm{K}$ levels.

Since Tuberculosis (TB) is one of the most prevalent causes of adrenal insufficiency, the patient was addressed to take a chest X-ray to evaluate any pulmonary or cardiac problem, which showed no evidence of parenchymal diseases or consolidations in the lung and the heart had normal shape, size and position. More over PPD test was negative as well (Figure 5).

Table 1. Laboratory findings

\begin{tabular}{|c|c|c|c|}
\hline & Result & Unit & Normal range \\
\hline \multicolumn{4}{|c|}{ Blood biochemistry: } \\
\hline FBS & 93 & $\mathrm{mg} / \mathrm{dl}$ & $60-110$ \\
\hline Creatinine & 1.16 & $\mathrm{mg} / \mathrm{dl}$ & $0.6-1.2$ \\
\hline ALT & 16 & $\mathrm{U} / \mathrm{L}$ & $<31$ \\
\hline AST & 20 & $\mathrm{U} / \mathrm{L}$ & $<31$ \\
\hline ALP & 250 & $\mathrm{U} / \mathrm{L}$ & $64-306$ \\
\hline Bili.T & 1.01 & $\mathrm{mg} / \mathrm{dl}$ & $0.1-1.2$ \\
\hline Bili.D & 0.17 & $\mathrm{mg} / \mathrm{dl}$ & \\
\hline LDH & 337 & $\mathrm{U} / \mathrm{L}$ & $160-420$ \\
\hline Calcium & 8.9 & $\mathrm{mg} / \mathrm{dl}$ & $8.5-10.8$ \\
\hline CPK & 49 & $\mathrm{U} / \mathrm{L}$ & $<110$ \\
\hline Amylase & 69 & $\mathrm{U} / \mathrm{L}$ & $<90$ \\
\hline $\mathrm{Na}$ & 132.8 & $\mathrm{mEq} / \mathrm{L}$ & \\
\hline K & 6.97 & $\mathrm{mEq} / \mathrm{L}$ & \\
\hline
\end{tabular}

Hormones :

\begin{tabular}{|c|c|c|c|}
\hline TSH-ECL & 13.9 & $\mu \mathrm{IU} / \mathrm{mL}$ & $0.27-4.2$ \\
\hline $\begin{array}{l}\text { Thyroxin total } \\
\text { (T-4)-ECL }\end{array}$ & 76.1 & $\mathrm{nmol} / \mathrm{L}$ & $66-181$ \\
\hline OH VitD-25 & 3.90 & $\mathrm{ng} / \mathrm{mL}$ & \\
\hline A.C.T.H & $>1250$ & $\mathrm{pg} / \mathrm{mL}$ & $0.1-46$ \\
\hline Cortisol-ECL (AM) & 4.28 & $\mathrm{mg} / \mathrm{dL}$ & $5-25$ \\
\hline
\end{tabular}




\begin{tabular}{|c|c|c|c|c|}
\hline & Result & Unit & Normal range & \\
\hline Anti TPO-IgG & 38.5 & $\mathrm{IU} / \mathrm{mL}$ & Up to 35 & \\
\hline \multicolumn{5}{|l|}{ C.B.C } \\
\hline W.B.C & 6.3 & $\mathrm{X} 10^{\wedge} 3 / \mu \mathrm{L}$ & & \\
\hline R.B.C & 4.92 & $\mathrm{X} 10^{\wedge} 6 / \mu \mathrm{L}$ & & \\
\hline Н.В & 15.3 & $\mathrm{gr} / \mathrm{dL}$ & $12-16$ & \\
\hline H.C.T & 44.8 & $\%$ & & \\
\hline PLT & 172 & $\mathrm{X} 10^{\wedge} 3 / \mu \mathrm{L}$ & & $150-450$ \\
\hline \multicolumn{5}{|l|}{ Urinanalysis } \\
\hline Color & Yellow & & & \\
\hline Blood & Negative & & & \\
\hline Protein & Negative & & & \\
\hline Glucose & Negative & & & \\
\hline Ketone & Negative & & & \\
\hline W.B.C & $3-4$ & $/ \mathrm{hpf}$ & & \\
\hline R.B.C & $0-1$ & /hpf & & \\
\hline
\end{tabular}
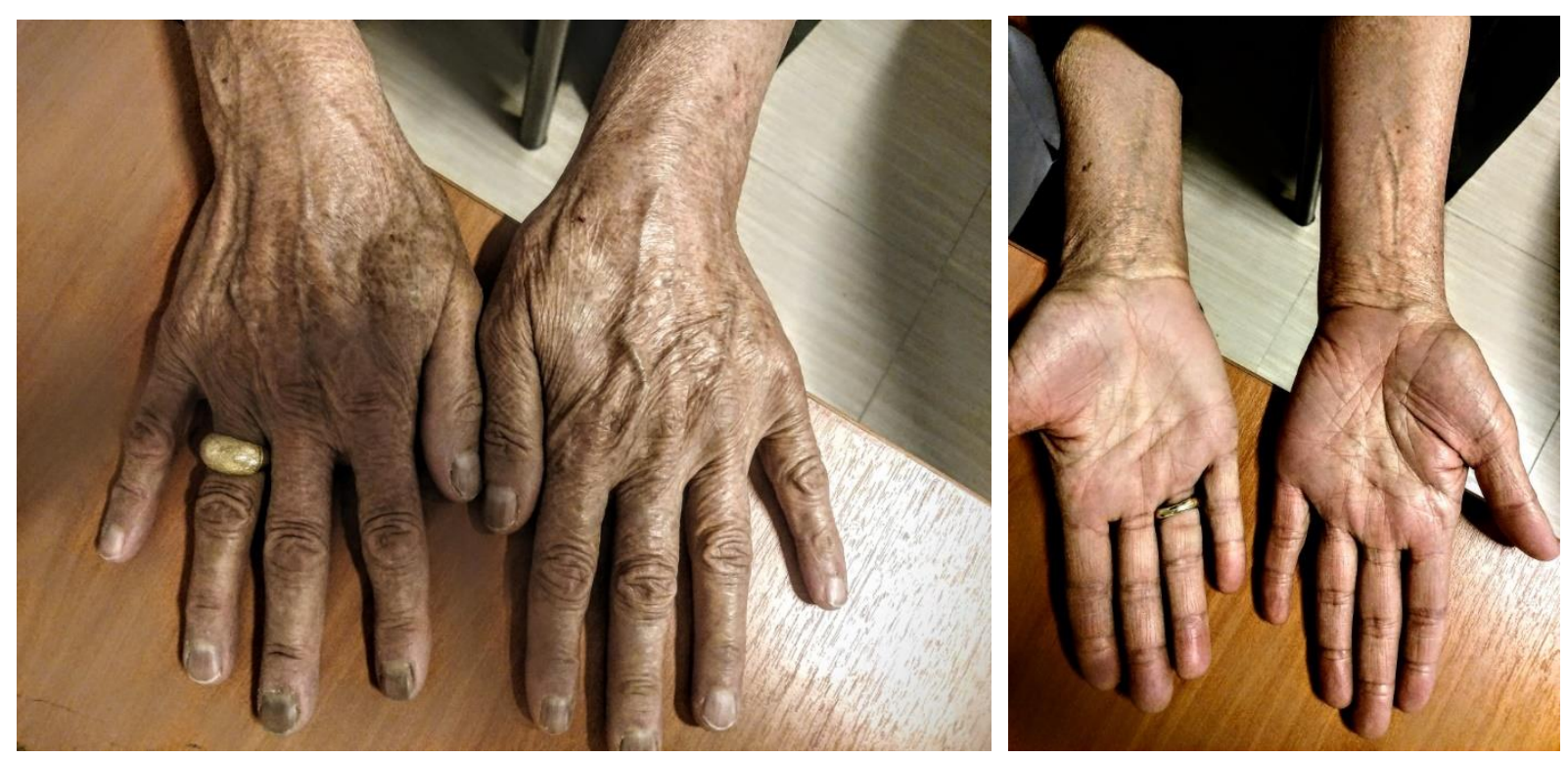

Figure 1\&2. Darkening of the skin and hyperpigmentations on hands 

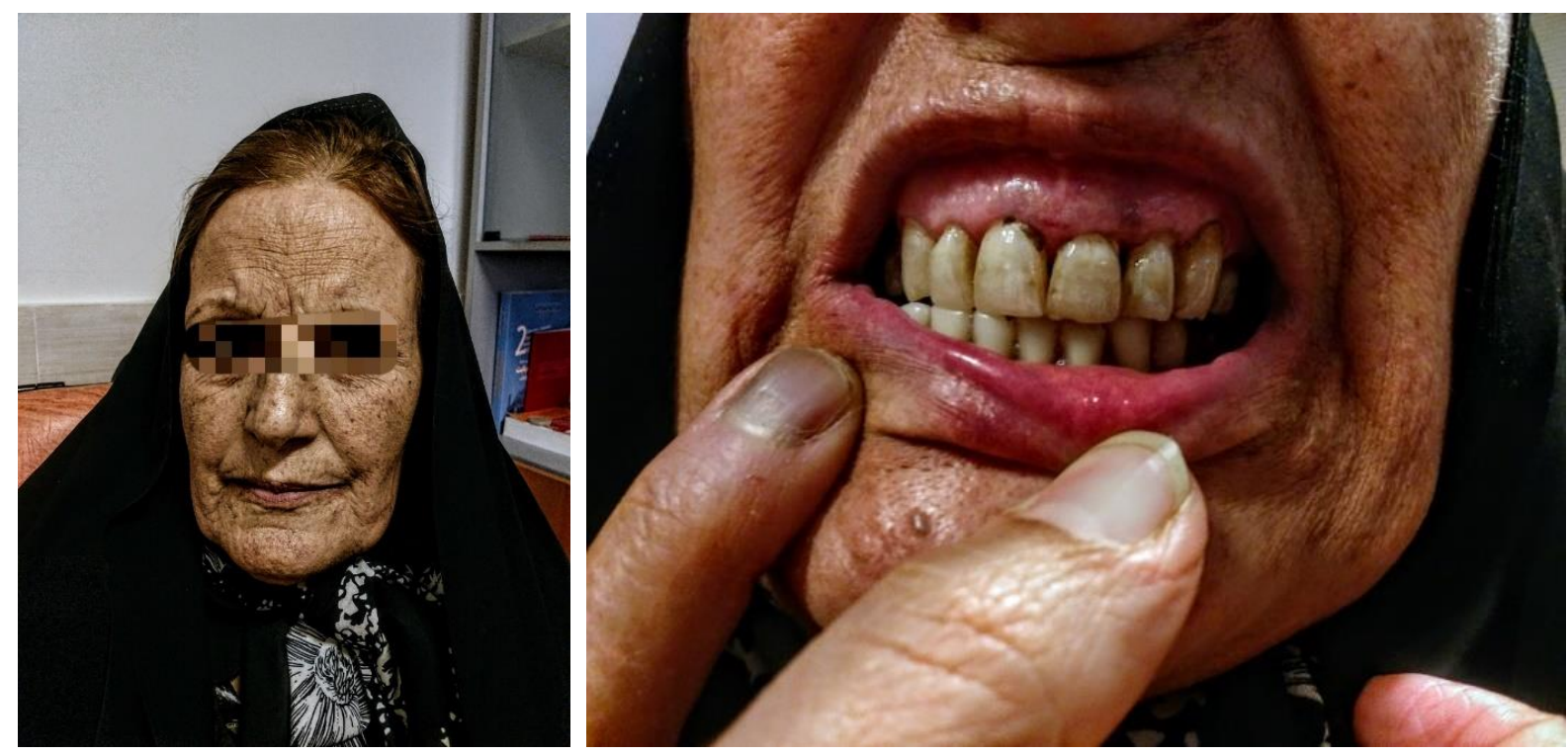

Figure 3 \& 4. Hyperpigmantations on the face and around teeth and mucus membranes

Table 2. Following up $\mathrm{Na}$ and $\mathrm{K}$

\begin{tabular}{|cccc} 
& Result & Unit & Reference range \\
\hline Blood Biochemistry: & 140 & $\mathrm{mEq} / \mathrm{l}$ & $135-148$ \\
\hline Sodium (NA)-ISE & 4.6 & $\mathrm{mEq} / \mathrm{L}$ & $3.5-5$ \\
\hline Potassium (K)-ISE & 18.1 & $\mathrm{ng} / \mathrm{mL}$ & $30-150$ \\
\hline 25-OH Vit D3 & & & \\
\hline
\end{tabular}

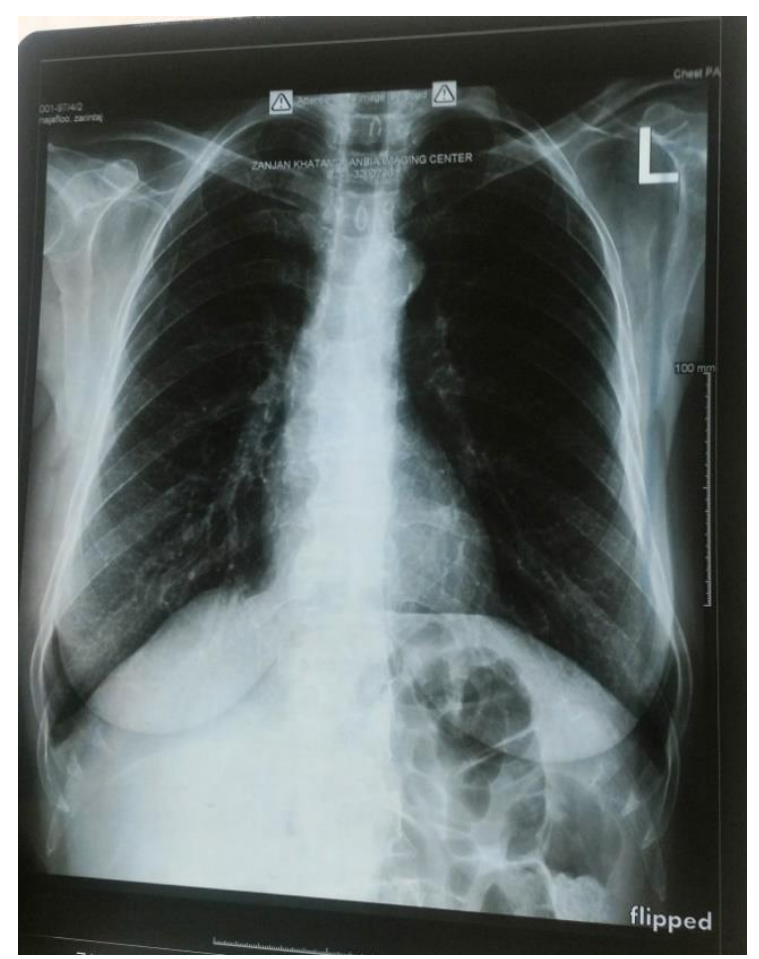

Figure 5. Chest X-Ray for chasing the trace of $\mathrm{TB}$ and evaluating any pulmonary or cardiac problem

\section{Discussion}

The term APS-2 is defined when an individual has at least 2 out of 3 of the following manifestations: Addison's disease, autoimmune thyroid disease and type 1 diabetes mellitus. APS-2 is a rare condition; with an incidence of 1-2/100 000 per year. The female-tomale ratio of APS2 is 3-4:1(5,6). APS2 is a condition that generally presents in the third and fourth decades of life $(3,7)$. Our patient's presentation with adrenal insufficiency at the age of 70 was thus unusual and it is probable that her adrenal autoimmunity had been present for a remarkable time prior to development of clinical manifestation and diagnosis as it was mentioned by the patient that the symptoms began to appear gradually from 10 years ago. It is worth mentioning that the clinical features of Addison's disease do not begin to appear until at least $90 \%$ of the glandular tissue has been destroyed.

Different literatures found different data on coexistence of the three main diseases. However, coexistence of T1DM and thyroid disease was most common while the coexistence of Addison's and thyroid disease was less common (8). 
There were no symptoms or signs of other endocrine and non-endocrine manifestations of APS-2, like celiac disease, alopecia, vitiligo, primary hypogonadism, myasthenia gravis, IgA deficiency, pernicious anemia, idiopathic heart block, Stiff-man syndrome, Parkinson's disease, serositis, dermatitis herpetiformis, idiopathic thrombocytopenia, and hypophysitis in our patient (3).

Although etiology of APS-2 is still under further evaluations, as far as known, it is a polygenic disease, with significant heterogeneity due to multiple genetic loci and environmental factors. Genetic studies revealed histocompatibility complex $(M H C)$ genes located on chromosome 6 are involved in organspecific damage. It appears that the syndrome is more prevalent in patients associated with specific HLADR3 and HLA-DR4 haplotypes and the class 2 HLA alleles DQ2 and DQ8; Non-HLA genes including CD25-interleukin-2 receptor, cytotoxic T-lymphocyte protein 4 (CTLA-4), and protein tyrosine-protein phosphatase, non-receptor type 22 (PTPN22) can also increase predisposition to APS-2 $(\mathbf{1 , 9 , 1 0 )}$. Unfortunately nor genetic study neither the level of 21hydroxylase is measureable at our center to find out genomes variability and presence of anti-21 hydroxylase antibody in our patient.

\section{Conclusion}

Patients affected with APS-2 may experience multiple challenges and also carry a significant burden due to the complexity of the disease. When there is an involvement of a single endocrine gland there can be possibility of involvement of a second gland at later date. In patients like ours which are having mild elevation of TSH with borderline levels of T4 which is accounted as subclinical hypothyroidism, not only should it be neglected by the patient, but also it should rise the suspicious for polyglandular syndromes, thus evaluating them clinically should be taken under consideration. Consequently specific tests should be performed if additional immune diseases are suspected.

\section{Acknowledgment}

The authors thank all those who helped them writing this paper.

\section{Conflict of Interest}

Authors declared no conflict of interests.

\section{References}

1. Husebye ES, Anderson MS, Kämpe O. Autoimmune polyendocrine syndromes. N Engl J Med. 2018; 378(12): 1132-41. [DOI:10.1056/NEJMra1713301]

2. Sperling $\mathrm{M}$, Yau M. Autoimmune polyglandular syndromes. In: De Groot LJ, Chrousos G, Dungan K, et al., editors. Endotext [Internet]. South Dartmouth (MA): MDText.com, Inc.; 2000-. Available from: https://www.ncbi.nlm.nih.gov/books/NBK279152

3. Dittmar M, Kahaly GJ. Polyglandular autoimmune syndromes: immunogenetics and long-term follow-up. J Clin Endocrinol Metab. 2003; 88(7): 2983-92 [DOI:10.1210/jc.2002-021845]

4. Singh G, Jialal I. Polyglandular autoimmune syndrome, Type II (Carpenters, Schmidt). In: StatPearls [Internet]. Treasure Island (FL): StatPearls Publishing; 2018 Jan-. Available from: https://www.ncbi.nlm.nih.gov/books/NBK525992/

5. Förster G, Krummenauer F, Kühn I, Beyer J, Kahaly G. Polyglandular autoimmune syndrome type II: epidemiology and forms of manifestation. Dtsch. Med. Wochenschr. 1999; 124(49):1476-81. [DOI:10.1055/s2008-1035684]

6. Cooper GS, Stroehla BC. The epidemiology of autoimmune diseases. Autoimmun Rev. 2003. 2(3): 119-25 [DOI:10.1016/S1568-9972(03)00006-5]

7. Michels A, Gottlieb P. Autoimmune polyglandular syndromes. Nat Rev Endocrinol. 2010; 6(5): 270-7 [DOI:10.1038/nrendo.2010.40]

8. Cutolo M. Autoimmune polyendocrine syndromes. Autoimmun Rev. 2014; 13(2): $\quad 85-9$ [DOI:10.1016/j.autrev.2013.07.006]

9. Simmonds MJ, Gough SC. Unravelling the genetic complexity of autoimmune thyroid disease: HLA, CTLA-4 and beyond. Clin Exp Immunol. 2004; 136(1): 1-10. [DOI:10.1111/j.1365-2249.2004.02424.x]

10. Erichsen MM, Lovas K, Skinningsrud B, et al. Clinical, immunological, and genetic features of autoimmune primary adrenal insufficiency: observations from a norwegian registry. J Clin Endocrinol Metab. 2009; 94(12): 4882-90 [DOI:10.1210/jc.2009-1368]

Besharati S, Tavakkolian P, Borji R. Autoimmune Polyglandular Syndrome Type 2 (APS-2) in A 70-Year-Old Woman: A Case Report. J Adv Med Biomed Res. 2019; 27 (124): 47-51

\section{Download citation: \\ Send citation to: \\ Mendeley 2 Zotero ;)RefWorks RefWorks}

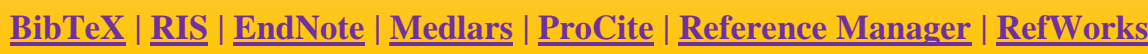

